OPEN ACCESS

Edited by: Hongyin Zhang, Jiangsu University, China

Reviewed by: Bartolome Moya Canellas, University of Florida, United States

Hetong Lin,

Fujian Agriculture and Forestry University, China

${ }^{*}$ Correspondence: Achour Amir

a.amiri@wsu.edu

Specialty section:

This article was submitted to

Food Microbiology,

a section of the journal

Frontiers in Microbiology

Received: 29 June 2018

Accepted: 27 September 2018

Published: 31 October 2018

Citation:

Ali EM and Amiri A (2018)

Selection Pressure Pathways and Mechanisms of Resistance to the

Demethylation

Inhibitor-Difenoconazole in Penicillium expansum. Front. Microbiol. 9:2472.

doi: 10.3389/fmicb.2018.02472

\title{
Selection Pressure Pathways and Mechanisms of Resistance to the Demethylation Inhibitor-Difenoconazole in Penicillium expansum
}

\section{Emran Md Ali and Achour Amiri*}

Department of Plant Pathology, Tree Fruit Research and Extension Center, Washington State University, Wenatchee, WA, United States

Penicillium expansum causes blue mold, the most economically important postharvest disease of pome fruit worldwide. Beside sanitation practices, the disease is managed through fungicide applications at harvest. Difenoconazole (DIF) is a new demethylation inhibitor (DMI) fungicide registered recently to manage postharvest diseases of pome fruit. Herein, we evaluated the sensitivity of $130 \mathrm{P}$. expansum baseline isolates never exposed to DIF and determined the effective concentration $\left(E_{50}\right)$ necessary to inhibit $50 \%$ germination, germ tube length, and mycelial growth. The respective mean $\mathrm{EC}_{50}$ values of $0.32,0.26$, and $0.18 \mu \mathrm{g} / \mathrm{ml}$ indicate a high sensitivity of $P$. expansum baseline isolates to DIF. We also found full and extended control efficacy in vivo after 6 months of storage at $1^{\circ} \mathrm{C}$. We conducted a risk assessment for DIF-resistance development using ultraviolet excitation combined with or without DIF-selection pressure to generate and characterize lab mutants. Fifteen DIF-resistant mutants were selected and showed $E_{50}$ values of 0.92 to $1.4 \mu \mathrm{g} / \mathrm{ml}$ and 1.7 to $3.8 \mu \mathrm{g} / \mathrm{ml}$ without and with a DIF selection pressure, respectively. Resistance to DIF was stable in vitro over a 10-week period without selection pressure. Alignment of the full CYP51 gene sequences from the three wild-type and 15 mutant isolates revealed a tyrosine to phenylalanine mutation at codon 126 (Y126F) in all of the 15 mutants but not in the wild-type parental isolates. Resistance factors increased 5 to 15 -fold in the mutants compared to the wild-type-isolates. DIF-resistant mutants also displayed enhanced CYP51 expression by 2 to 14-fold and was positively correlated with the $\mathrm{EC}_{50}$ values $\left(R^{2}=0.8264\right)$. Cross resistance between DIF and fludioxonil, the mixing-partner in the commercial product, was not observed. Our findings suggest $P$. expansum resistance to DIF is likely to emerge in commercial packinghouse when used frequently. Future studies will determine whether resistance to DIF is qualitative or quantitative which will be determinant in the speed at which resistance will develop and spread in commercial packinghouses and to develop appropriate strategies to extend the lifespan of this new fungicide.

\footnotetext{
Keywords: demethylation inhibitors, blue mold, CYP51, postharvest, fludioxonil, overexpression
} 


\section{INTRODUCTION}

The extended storage of apple fruit for up to 12 months in low temperatures and controlled atmospheres (low $\mathrm{O}_{2}$ and high $\mathrm{CO}_{2}$ concentrations) makes them prone to infections by several fungal pathogens. Penicillium expansum is an ascomycete fungus causing blue mold, a major postharvest disease of apple and pear fruit worldwide (Amiri and Bompeix, 2005a; Morales et al., 2007; Jurick et al., 2011). In recent surveys in Washington State, blue mold accounted for nearly $50 \%$ of total decay caused on apple postharvest (Amiri and Ali, 2016). Penicillium expansum is a typical airborne and wound pathogen with short life cycles and copious asexual conidial production which are responsible for pome fruit infections in storage rooms (Sanderson and Spotts, 1995; Amiri and Bompeix, 2005a). Spores of P. expansum seldom infect fruit in orchards (Amiri and Bompeix, 2005a) but can be abundant on storage bins and in storage rooms if appropriate sanitation practices are not implemented at the beginning of the season (Spotts and Cervantes, 1993; Sanderson and Spotts, 1995; Amiri and Bompeix, 2005a). Primary infections, resulting from residual inoculum, may start on fresh wounds or punctures caused at harvest or during postharvest handling (Rosenberger et al., 1991; Amiri and Bompeix, 2005b). Thereafter, inoculum can quickly build up inside storage rooms to cause multiple secondary infections (Amiri and Bompeix, 2005a).

There is no known host resistance to $P$. expansum in current commercial apple cultivars. Therefore, besides some sanitation practices at packing facilities and other biological or physical methods with moderate efficacy, management of $P$. expansum and other postharvest pathogens is mainly achieved using singlesite synthetic fungicides. The number of molecules registered postharvest has been limited to three, i.e., thiabendazole (TBZ) registered four decades ago, pyrimethanil (PYR) and fludioxonil (FDL) registered 15 years ago. P. expansum is considered a "high risk" fungus for fungicide resistance development. Thus, resistance to TBZ, linked to several mutations in the $\beta$-tubulin gene, has been reported widely from numerous production regions worldwide (Rosenberger et al., 1991; Errampalli et al., 2006; Malandrakis et al., 2013; Yin and Xiao, 2013). Resistance to PYR has emerged in recent years in the U.S. Pacific Northwest and Mid-Atlantic regions but remains at relatively low frequencies (Jurick et al., 2017; Caiazzo et al., 2014; Yan et al., 2014; Amiri et al., 2018). Lately, low levels of resistance or reduced sensitivity to FDL have been sporadically found in some U.S. apple packinghouses (Gaskins et al., 2015; Amiri et al., 2017). The emergence of resistance to PYR and FDL and the relatively lower FDL efficacy against Neofabraea spp. (Amiri, unpublished data) suggest registration of new fungicides with different modes of action than the current three postharvest fungicides is necessary to maintain effective disease control.

Difenoconazole (1-[2-[2-chloro-4-(4-chloro-phenoxy)phenyl]-4-methyl[1,3]-dioxolan-2-ylmethyl]-1H-1,2,4-triazole) (Supplementary Figure S1), a new demethylation inhibitor (DMI) fungicide, was registered in 2016 for postharvest use in pome fruit. It is pre-mixed with FDL and commercially available as Academy ${ }^{\mathrm{TM}}$ (Syngenta Crop Protection). Difenoconazole
(DIF) has a systemic activity and broad-spectrum antifungal potency as shown recently (Hof, 2001; Fonseka and Gudmestad, 2016; Bartholomäus et al., 2017; Dang et al., 2017; Jurick et al., 2017; Koehler and Shew, 2018; Ali et al., 2018). DMIs, such as DIF, target the sterol $14 \alpha$-Demethylase Cytochrome P450 (CYP51), an essential component of fungal membrane sterols required for a proper membrane functioning (Rodriguez et al., 1985; Joseph-Horne and Hollomon, 1997). Although classified as "medium risk," resistance to DMIs has been reported in several fungal pathogens (Golembiewski et al., 1995; Erickson and Wilcox, 1997; Schnabel and Jones, 2001; Fraaije et al., 2007; Omrane et al., 2015), i.e., in Penicillium digitatum from citrus fruit (Eckert and Ogawa, 1988; Bus et al., 1991; Hamamoto et al., 2001a; Ghosoph et al., 2007; Sun et al., 2011). Resistance to the DMIs in P. digitatum and other micro-organisms has been linked to single amino-acid alterations in the target site (Délye et al., 1997; Favre et al., 1999; Diaz-Guerra et al., 2003; Leroux et al., 2007; Wang et al., 2015; Pereira et al., 2017), increased energy dependent fungicide efflux mechanisms (Nakaune et al., 1998; Reimann and Deising, 2005), or overexpression of the CYP51 gene (Van Den Brink et al., 1996; Hamamoto et al., 2001a; Schnabel and Jones, 2001; Sun et al., 2013). A mechanism involving both amino-acid alterations with overexpression of the CYP51 gene has been suggested to cause DMI resistance in some other fungi (Mellado et al., 2007; Snelders et al., 2008; Mair et al., 2016; Lichtemberg et al., 2017).

The widespread resistance of $P$. expansum to two of the three existing postharvest fungicides and the fact that DIF will be premixed with FDL for which some tolerance has already been reported suggest a thorough risk assessment is needed before DIF becomes widely used. Herein, we evaluated the sensitivity of a baseline wild-type $P$. expansum population to DIF, determined impact of storage conditions on fungicide potency, and evaluated the risk and mechanisms of resistance development to DIF in lab mutants of $P$. expansum. We show that DIF would be a useful tool to include in future management programs but strategies are needed to extend its lifespan.

\section{MATERIALS AND METHODS}

\section{Cultivation and Characterization of $P$. expansum Baseline Isolates}

A total of $130 \mathrm{P}$. expansum isolates, never exposed to difenoconazole (DIF), collected in 2004 and 2005 were used to determine the baseline sensitivity. These isolates were singlespored and stored in $20 \%$ glycerol at $-80^{\circ} \mathrm{C}$ at the WSU-TFREC pathology laboratory. Isolates were identified to the species level based on the $\beta$-tubulin gene using the PE-Chang5'-F and PETub-R2 primer pair (Supplementary Table S1) developed in this study and based on a previous work published by Sholberg et al. (2005). Prior to each experiment, the isolates were grown on potato dextrose agar (PDA) at $22^{\circ} \mathrm{C}$ for 5 to 7 days or until profuse sporulation was observed. Three wild-type isolates, Pe3175, Pe3136, and Pe3334, were used for mutant selection as described below. 


\section{Fungicides}

Formulated difenoconazole (DIF, Thesis, Syngenta Crop Protection, Greensboro, NC, United States), fludioxonil (Scholar SC, Syngenta), and fluioxonil + difenoconazole (Academy, Syngenta) were used in this study. For in vitro bioassay, stock solutions of $1,000 \mu \mathrm{g} / \mathrm{ml}$ of the active ingredients were made in sterile distilled water and stored in the dark at $4^{\circ} \mathrm{C}$ for no more than 21 days. Preliminary tests showed no negative effect of sensitivity levels of fungicide stocks prepared and stored as described above (data not shown). DIF was used to determine the baseline sensitivity of the 130 baseline isolates and selected mutants, whereas fludioxonil (FDL) was used to determine cross-sensitivity with DIF in mutant isolates. For in vivo assays, the formulated products were used following the label rate or as otherwise described.

\section{Determination of Baseline Sensitivity to Difenoconazole}

The sensitivity of 130 baseline isolates to DIF was determined in vitro using mycelial growth, spore germination, and germ tube inhibition assays on $1 \%$ malt extract agar (MEA) medium. Molten autoclaved MEA was cooled to $50^{\circ} \mathrm{C}$ and DIF was added from the stock to obtain final concentrations of $0.0,0.05,0.1,0.5,5.0$, and $10.0 \mu \mathrm{g} / \mathrm{ml}$ and poured into $60-\mathrm{mm}$ Petri plates. Spores were harvested from 7-day-old plates by transferring dry spores with a sterile plastic loop to a 2-ml tube containing $1 \mathrm{ml}$ of sterile deionized water with $0.05 \%$ Tween 20 . The spore concentrations were determined with a hemacytometer and adjusted to $10^{5}$ spores $/ \mathrm{ml}$. A $10 \mu \mathrm{l}$-droplet was plated onto the center of a DFCamended and non-amended MEA plates, which were incubated for 6 days at $20^{\circ} \mathrm{C}$ before measuring the colony diameter. The spore germination inhibition assay was conducted on MEA as described for mycelial growth except that spore germination was measured microscopically after $16 \mathrm{~h}$ incubation at $20^{\circ} \mathrm{C}$. A conidium was considered germinated when the germ tube length was at least twice the conidium diameter. The germ tube length of 10 conidia per plate was measured using the reticle ruler and used to assess sensitivity based on germ tube length inhibition. For each bioassay, trials were conducted in quadruplicates and repeated twice.

\section{Generation and Characterization of DIF-Resistant Mutants}

\section{Mutants Generation}

Three $P$. expansum wild-type isolates, Pe3175, Pe3136, and Pe3334, were used as parental isolates to generate fungicideresistant mutants using ultraviolet (UV) light excitation as described by Li and Xiao (2008) with some modifications. For each isolate, a $100 \mu \mathrm{l}$-aliquot of a spore suspension at $3.7 \times 10^{7}$ conidia per ml was spread onto PDA media amended with $10 \mu \mathrm{g} / \mathrm{ml}$ DIF. Five replicate-plates were used for each of the three isolates and the plates were incubated at $20^{\circ} \mathrm{C}$ for $5 \mathrm{~h}$ in the dark before exposition to UV light (plates $27 \mathrm{~cm}$ from the UV light at $253.7 \mathrm{~nm}$ ) for $30 \mathrm{~s}$ followed by a 7-day- incubation in the dark at $20^{\circ} \mathrm{C}$. Growing colonies, including from the non-UV exposed WT parental isolates, were transferred twice on PDA amended with DIF at $10 \mu \mathrm{g} / \mathrm{ml}$ and incubated for 6 days for each transfer. Thereafter, colonies were grown and transferred twice on DIFfree PDA and incubated at $20^{\circ} \mathrm{C}$. No growth was observed on the WT isolates grown on PDA with $10 \mu \mathrm{g} / \mathrm{ml}$ after 12 days of incubation (data not shown).

\section{Evaluation of Resistance of Mutants to DIF and Its Stability With and Without Selection Pressure}

Five colonies were selected from each wild-type parent and the total of 15 mutants were characterized for their sensitivity to DIF using a mycelial growth assay as described above for the baseline isolates. The stability of resistance to DIF was evaluated without and with DIF selection pressure. Nine isolates, i.e., three WT-isolates Pe3136, Pe3175, and Pe3334 and three mutants selected from each of them, were used. A 10- $\mu$ l droplet of a spore suspension $\left(10^{4} \mathrm{spores} / \mathrm{ml}\right)$ of each isolate was transferred to fresh free-DIF MEA plates (three replicates/isolates) to test for stability in absence of selection pressure or onto MEA plates amended with DIF at $2.5 \mu \mathrm{g} / \mathrm{ml}$ to test with selection pressure. Isolates were incubated for 1 week at $20^{\circ} \mathrm{C}$, then transferred weekly on DIF-free or DIF-amended plates for seven additional successive weeks. After 8 weeks, the $\mathrm{EC}_{50}$ values were determined based on a mycelial growth inhibition assay and compared with the initial $\mathrm{EC}_{50}$ values of the $\mathrm{WT}$ and the mutant isolates.

\section{Virulence on Apple Fruit and Efficacy of DIF to Control Resistant Mutants}

Organic cv. Fuji apples harvested at commercial maturity from an experimental orchard in East Wenatchee, Washington, were surface-disinfected for $3 \mathrm{~min}$ in $0.8 \%$ sodium hypochlorite, rinsed twice with sterile water and air-dried. Fruits were punctured twice near the stem-end area with a sterile needle $(1.5 \mathrm{~mm}$ diameter, $3 \mathrm{~mm}$ deep), dipped for $30 \mathrm{~s}$ in a suspension of formulated DIF (Thesis, Syngenta) at label rate of $0.26 \mathrm{mg} / \mathrm{L}$, allowed to dry at $4^{\circ} \mathrm{C}$ for $12,24,48$, and $96 \mathrm{~h}$ then inoculated with a $25-\mu \mathrm{l}$ droplet of spore suspension $\left(5 \times 10^{4}\right.$ spores $\left./ \mathrm{ml}\right)$ on each wound. Control fruit were wounded and dipped in sterile water. The three WT-baseline isolates, Pe3334 $\left(\mathrm{EC}_{50}=0.13 \mu \mathrm{g} / \mathrm{ml}\right), \operatorname{Pe} 3136$ $\left(\mathrm{EC}_{50}=0.21 \mu \mathrm{g} / \mathrm{ml}\right)$, and Pe3175 $\left(\mathrm{EC}_{50}=0.29 \mu \mathrm{g} / \mathrm{ml}\right)$, and nine lab DIF-mutants that had $\mathrm{EC}_{50}$ values ranging from 0.6 to $3.7 \mu \mathrm{g} / \mathrm{ml}$ were used for inoculation. Eight replicate fruit in duplicate were used for each isolate and fungicide combination and the trials were conducted twice. Inoculated fruit (two reps of four fruit each per each treatment) were incubated in separate sterile boxes in saturated growth chambers at $0^{\circ} \mathrm{C}$ and a regular atmosphere. Disease incidence and severity were determined relative to untreated control fruit monthly up to 6 months of storage.

\section{Cross-Sensitivity With Fludioxonil and Efficacy of Academy $^{\mathrm{TM}}$ to Control DIF-Resistant Mutants}

Difenoconazole is pre-mixed with fludioxonil (FDL) and registered as Academy ${ }^{\mathrm{TM}}$ for commercial use. Therefore, we verified that the DIF-lab mutants were not resistant to FDL. The three parental wild-type isolates, Pe3136, Pe3175, Pe3334, and the 15 DIF-resistant mutants selected were tested on PDA amended with FDL at $0,0.001,0.01,0.1,1.0$, and $10.0 \mu \mathrm{g} / \mathrm{ml}$. 
Sensitivity tests were conducted based on a mycelial growth assay as described above for the baseline isolates. Three replicate plates were used for each isolate and fungicide concentration and the experiment was repeated twice.

A detached fruit assay was conducted to evaluate the efficacy of the mixture DIF + FDL (Academy ${ }^{\mathrm{TM}}$, Syngenta) to control DIFresistant mutants. Organic Fuji apples were prepared as described above for virulence assay and treated preventively with Academy at $1.25 \mathrm{ml} / \mathrm{L}(0.26 \mathrm{mg} \mathrm{DIF} / \mathrm{L})$, then inoculated $4 \mathrm{~h}$ later with spore suspensions at $5 \times 10^{4}$ spores/ml of the parental wild-type isolate Pe3175 and two of its mutants. The number of replicate fruit, storage conditions and assessments of disease incidence and severity were conducted similarly to virulence assays above.

\section{Amplification and Sequencing of the PeCYP51 Gene}

DNA of the three WT parental isolates and 15 mutants, i.e., 5 mutants from each WT isolate, was extracted from DIF-free 14 day-old-PDA plates using the FastDNA Kit (MP Biomedicals, Solon, OH, United States) according to the supplier's instructions. The quantity and purity of DNA was measured with a NanoDrop Spectrophotometer (ND-1000, NanoDrop Technology, Wilmington, DE, United States). Three sets of primers were developed (Supplementary Table S1) based on the sequences of CYP51 in GenBank accession numbers XM016737741 and NW015971309 (Supplementary Figure S2) and used to amplify $1751 \mathrm{bp}$ of the $P$. expansum CYP51 (PeCYP51) gene. The primer pair CYP51-S2F/CYP51S2R, developed based on the GenBank accession XM016737741, was used to amplify a $567 \mathrm{bp}$ fragment of the coding region. The two other sets of primers were developed to amplify parts of the CYP51 and the flanking regions based on the GenBank accession NW015971309. The primer set CYP51S5'F/CYP51-S1R was used to amplify an $811 \mathrm{bp}$ fragment including $137 \mathrm{bp}$ upstream of the $5^{\prime}$ end of CYP51 whereas the set CYP51-S3F/CYP51-S3'R was used to amplify an 884 bp fragment including 129 bp downstream the $3^{\prime}$ end of the CYP51 gene through conventional PCR. Fungal DNA (100 ng) was used as a template for $\mathrm{PCR}$ reactions which were run in 30 cycles of $94^{\circ} \mathrm{C}(30 \mathrm{~s}), 55^{\circ} \mathrm{C}(60 \mathrm{~s})$, and $72^{\circ} \mathrm{C}(60 \mathrm{~s})$ in a Bio-Rad T1000 thermocycler using EconoTaq ${ }^{\circledR}$ plus green $2 \times$ master mix (Lucigen, Middleton, WI, United States) following a protocol suggested by supplier. All PCR products were analyzed by electrophoresis on a $1 \%$ agarose gel, purified using a PCR purification kit (Qiagen, Valencia, CA, United States), and Sanger-sequenced at Retrogen, Inc. (San Diego, CA, United States). Sequences from the three fragments of the gene were concatenated and a multiple alignment was constructed using BioEdit Version 7.2.5 (Hall, 1999) to determine nucleotide and amino acid changes.

\section{RNA Extraction and Quantitative Expression of the PeCYP51 Gene}

Total RNA was isolated from DIF-free 14-day-old PDA plates using a ZR Fungal/Bacterial RNA MiniPrep Kit (Zymo Research, Irvine, CA, United States) according to the supplier's instructions. All RNA was analyzed for quantity and quality spectroscopically on $1 \%$ TBE agarose gel. After extraction, $1 \mu \mathrm{g}$ of total RNA from each sample was treated with DNase and single strand cDNA was synthesized using the Bio-Rad iScript $^{\mathrm{TM}}$ gDNA Clear cDNA Synthesis Kit (Bio-Rad Inc., Hercules, CA, United States). All samples were DNase-treated

TABLE 1 | Virulence of wild-type and mutants of Penicillium expansum on detached Fuji apples and in vivo control efficacy of preventive difenoconazole applications.

Blue mold incidence $(\%)$ and lesion diameter $(\mathrm{mm})$ on fruit treated or not with DFC

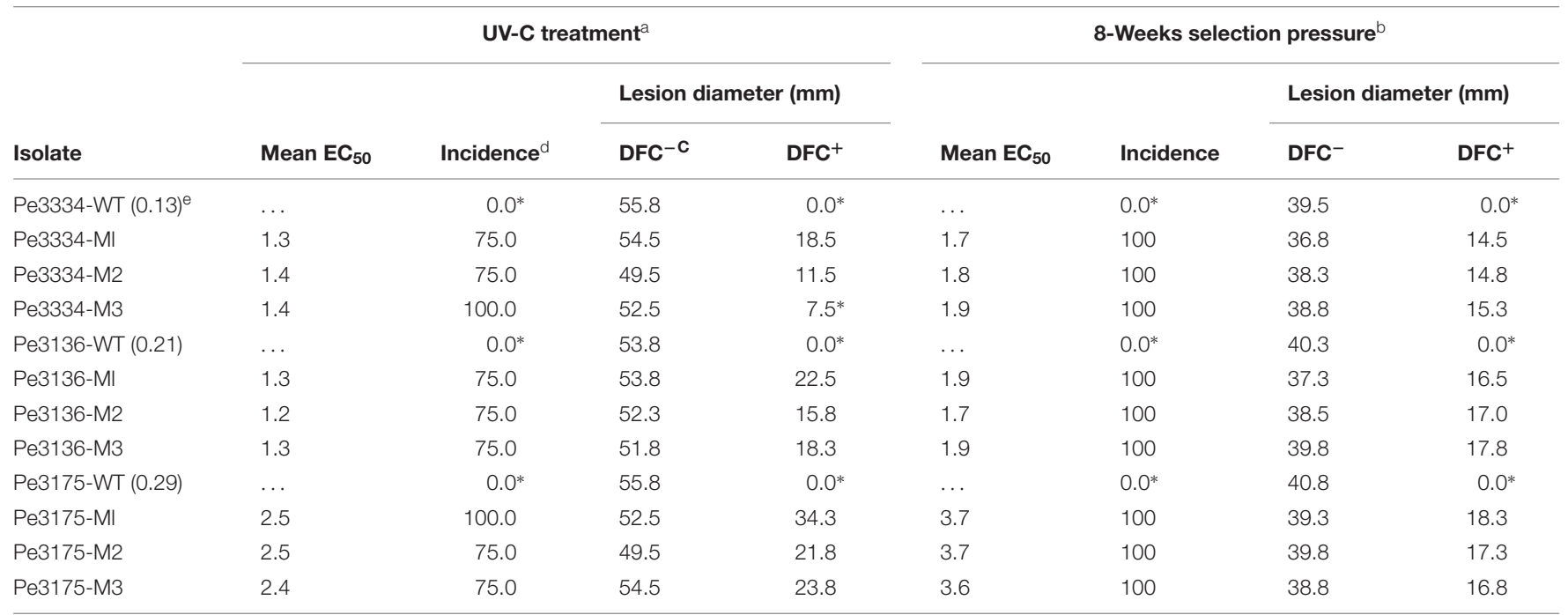

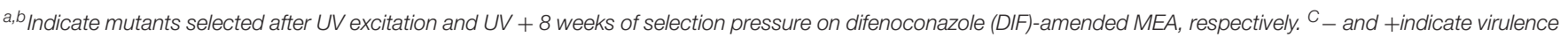

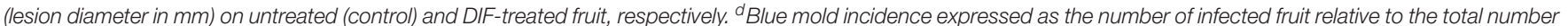

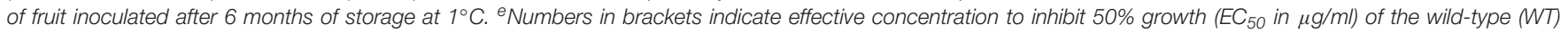
isolates. Values within the same column followed by an asterisk are statistically different from the other values based on an ANOVA test and Student' $t$-test at $P \leq 0.05$. 

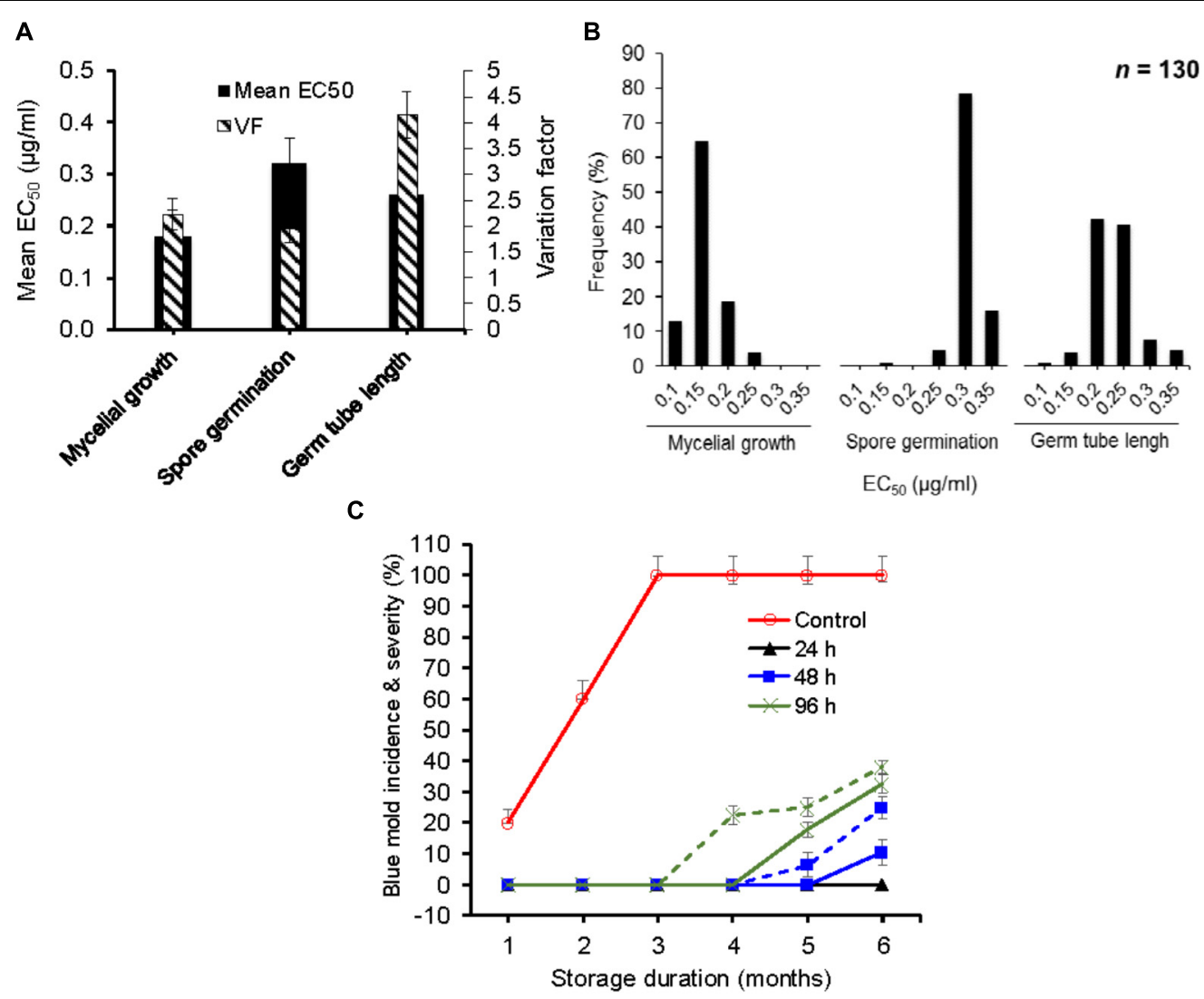

FIGURE 1 | In vitro and in vivo efficacy of difenoconazole against baseline isolates of Penicillium expansum. (A) Mean effective concentration of difenoconazole for $50 \%$ growth, germination and germ tube elongation inhibition $\left(\mathrm{EC}_{50}\right)$ and variation factor $\left(\mathrm{VF}\right.$, highest $\left.\mathrm{EC}_{50} / \mathrm{lowest}_{\mathrm{EC}} \mathrm{E}_{50}\right)$ of 130 baseline isolates of $P$. expansum. (B) Frequency distribution of respective $\mathrm{EC}_{50}$ values among 130 baseline isolates of $P$. expansum. (C) Temporal change in blue mold incidence (continuous lines) and severity (dashed lines) on detached apple fruit treated preventively with $0.26 \mathrm{mg} / \mathrm{L}$ of difenoconazole and inoculated with WT-isolates of $P$. expansum 24 , 48 , and $96 \mathrm{~h}$ post-treatment at $1^{\circ} \mathrm{C}$ and regular atmosphere. Data are the mean incidences from $3 \mathrm{WT}$-isolates (data were merged after no significance difference was observed between the isolates) and 58 fruit across two experimental runs. Data from the 12-h post-treatment inoculation are not shown because no disease was seen.

and cDNA synthesized in a single run with one batch of reagents and stored at $-80^{\circ} \mathrm{C}$. All quantitative (qPCR) reactions were run on a CFX96 ${ }^{\mathrm{TM}}$ Real-Time PCR Detection System using SsoAdvanced ${ }^{\mathrm{TM}}$ Universal SYBR ${ }^{\circledR}$ Green Supermix (BioRad Inc., Hercules, CA, United States) in a $10 \mu$ l-reaction volume containing $5 \mu \mathrm{l}$ of SYBR Green Supermix (antibodymediated hot-start Sso7d fusion polymerase, $50 \mathrm{mM} \mathrm{Na}^{+}$, $1.5 \mathrm{mM} \mathrm{Mg} 2^{+}, 1.2 \mathrm{mM}$ dNTPs, and $250 \mathrm{nM}$ annealing oligo), $0.3 \mu \mathrm{l}$ of $1000 \mathrm{nM}$ of each forward (cyp51A-F/ $\beta$-actinF) and reverse primers (cyp51A-R/ $\beta$-actin-R) (Table 1 ), and $2 \mu \mathrm{l}(10 \mathrm{pg})$ of $\mathrm{CDNA}$ and $2.4 \mu \mathrm{l}$ of PCR grade water. The recommended thermal cycling protocol for SsoAdvanced ${ }^{\mathrm{TM}}$ SYBR Green was used at an annealing/extension temperature of $60^{\circ} \mathrm{C}$, and a melt curve analysis was included. The CFX Maestro ${ }^{\text {TM }}$ Software $^{1}$ was used to analyze all qPCR data. The $2^{-\Delta \Delta C t}$ equation (Livak and Schmittgen, 2001) was used to calculate the relative gene expression using the $B$-actin as a reference control gene. CYP51 expression

\footnotetext{
${ }^{1}$ www.bio-rad.com
}

data presented herein are averages of nine values for each isolate across three separate experimental runs. The "sample maximization" experimental set-up for multi-plate qPCR studies was used to minimize technical variation between samples (Hellemans et al., 2007).

\section{Statistical Analysis}

Data from the two independent runs of in vitro and in vivo experiments were averaged when no statistical difference was observed between the two runs. Difenoconazole in vitro sensitivity data, expressed as percent inhibition relative to the control, were computed and log-transformed to calculate effective concentrations to inhibit $50 \%$ growth or germination $\left(\mathrm{EC}_{50}\right)$. Variation factors $(\mathrm{VF})$ were calculated as the highest $\mathrm{EC}_{50}$ value by the lowest $\mathrm{EC}_{50}$ value within the baseline population, whereas the resistance factors (RF) for DIFmutants were calculated as their $\mathrm{EC}_{50}$ value by the $\mathrm{EC}_{50}$ value of the parental WT-isolate. Virulence in vivo bioassay data were used to calculate disease incidence and severity. Gene expression was expressed as the ratio between CYP51 


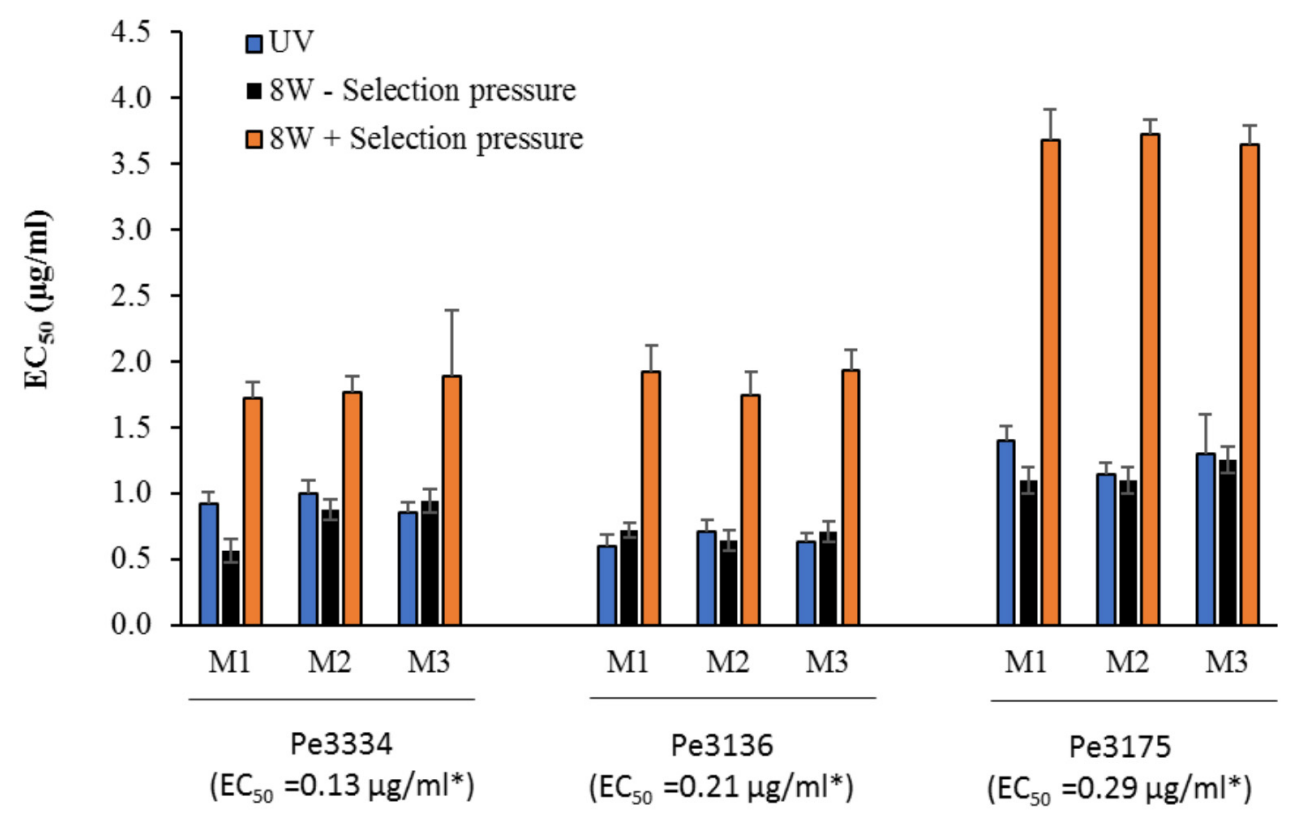

Parental wild-type isolates and derived mutants

FIGURE 2 | Mean effective concentration for $50 \%$ growth inhibition values (EC 50 ) of difenoconazole for DIF-resistant mutants selected following UV excitation of Pe3334, Pe3136, and Pe3175 P. expansum isolates or after 8 weeks of adaptation on MEA amended with DIF at $2.5 \mu \mathrm{g} / \mathrm{ml}$ (+ selection pressure, orange bars) or without (- selection pressure, black bars) at $22^{\circ} \mathrm{C}$. Asterisks indicates the $\mathrm{EC}_{50}$ values of each parental WT-isolate. Data are the mean of 12 values across two experimental runs for each mutant.

and $\beta$-actin genes. Data were subjected to ANOVA analyses and mean separations using Student $t$-test at $P<0.05$ in SAS software (Version 9.2, SAS Institute Inc., Cary, NC, United States).

\section{RESULTS}

\section{In vitro and in vivo Sensitivities of $P$. expansum Baseline Isolates to Difenoconazole}

The mean $\mathrm{EC}_{50}$ values $( \pm \mathrm{SD})$ for difenoconazole (DIF) determined for mycelial growth, spore germination and germ tube length inhibition were $0.17 \pm 0.03,0.32 \pm 0.02$, and $0.26 \pm 0.06 \mu \mathrm{g} / \mathrm{ml}$, respectively (Figure 1A). The $\mathrm{EC}_{50}$ values ranged from 0.13 to $0.29 \mu \mathrm{g} / \mathrm{ml}$ based on mycelial growth and from 0.19 to $0.37 \mu \mathrm{g} / \mathrm{ml}$ for spore germination inhibition and from 0.14 to $0.58 \mu \mathrm{g} / \mathrm{ml}$ for germ tube length inhibition (Figure 1B). The VF were 2.23, 1.95, and $4.14 \mu \mathrm{g} / \mathrm{ml}$, respectively. The frequency distribution of $\mathrm{EC}_{50}$ values for germ tube length and mycelial growth were the closest to a unimodal distribution with a right-hand tail (Figure 1B), contrary to spore germination, which had a left-hand tail.

The $\mathrm{EC}_{50}$ value of the $P$. expansum WT-isolates did not affect the efficacy of DIF in vivo since the three isolates Pe3175 $\left(\mathrm{EC}_{50}=0.13 \mu \mathrm{g} / \mathrm{ml}\right), \operatorname{Pe} 3334\left(\mathrm{EC}_{50}=0.21 \mu \mathrm{g} / \mathrm{ml}\right)$, and Pe3175 $\left(\mathrm{EC}_{50}=0.29 \mu \mathrm{g} / \mathrm{ml}\right)$ resulted in similar incidence and severity on detached fruit treated by the label rate of DIF. Therefore, data of the three isolates were averaged and presented in Figure 1C. The wild-type isolates were fully controlled on detached fruit for up to 6 months of storage at $0^{\circ} \mathrm{C}$ when DIF was applied 12 to $24 \mathrm{~h}$ pre-inoculation and for up to 4 months when DIF was applied preventively 48 or $96 \mathrm{~h}$ pre-inoculation (Figure 1C). After 6 months of storage, the blue mold incidence was 25 and 38\% on fruit inoculated 48 and $96 \mathrm{~h}$ pre-inoculation, respectively, and similar severity trend was observed.

\section{Characterizations of DIF-Resistant Mutants \\ Resistance Levels, Stability, Cross-Resistance With FDL and Efficacy of DIF in vivo}

In total, $15 P$. expansum mutants generated through UV excitation were tested for sensitivity to DIF using a mycelial growth inhibition assay to determine variation in their $\mathrm{EC}_{50}$ values compared to the parental wild-type (WT) isolates. The mutants selected from the parental WT isolates Pe3334 $\left(\mathrm{EC}_{50}=0.13 \mu \mathrm{g} / \mathrm{ml}\right)$ and Pe3136 $\left(\mathrm{EC}_{50}=0.21 \mu \mathrm{g} / \mathrm{ml}\right)$ had $\mathrm{EC}_{50}$ values ranging from 1.1 to 1.4 and respective $\mathrm{RF}$ ranging from 5.7 to 10.6 , whereas the mutants selected from the parental isolate $\mathrm{Pe} 3175\left(\mathrm{EC}_{50}=0.29 \mu \mathrm{g} / \mathrm{ml}\right)$ had $\mathrm{EC}_{50}$ values ranging from 2.1 to 2.5 (Table 1) and RFs from 7.7 to 8.8 . After 8 weekly transfers on MEA supplemented with DIF at $2.5 \mu \mathrm{g} / \mathrm{ml}$ (selection pressure), the $\mathrm{EC}_{50}$ values of the mutants ranged from 1.6 to $1.9 \mu \mathrm{g} / \mathrm{ml}$ for the mutants selected from the Pe3334 and Pe3136 WT isolates 
and from 3.3 to $3.7 \mu \mathrm{g} / \mathrm{ml}$ for the mutants selected from the parental isolate Pe3175 (Figure 2). RF values relative to the WT isolates ranged from 8 to 13 and increased by 1 to 1.5 -fold relative to the first mutants transfer (data not shown). After 10 weekly transfers on DIF-free MEA (no selection pressure), the $\mathrm{EC}_{50}$ values of DIF-resistant mutants decreased by 0.04 to $0.36 \mu \mathrm{g} / \mathrm{ml}$ for 6 mutants out of nine tested while $\mathrm{EC}_{50}$ increased in three mutants. However, EC $_{50}$ values were not significantly different from the first transfer and remained within the resistance range (Figure 2).

All the nine mutants originating from UV excitation caused blue mold on detached apple fruit and they were as virulent (lesion diameter) as the parental WT isolates (Table 1). While the three WT isolates were fully controlled by a preventive DIF application after 6 months of storage at $1^{\circ} \mathrm{C}$ (Table 1), the fungicide failed to control the nine selected mutants as the blue mold incidence ranged from 75 to $100 \%$ (Table 1 and Figure 3). The UV mutants adapted on $2.5 \mu \mathrm{g} / \mathrm{ml}$ of DIF for 8 weeks caused $100 \%$ blue mold incidence and their virulence (lesion diameter) was not significantly reduced compared to same isolate at the first transfer (Table 1 and Figure 3).

The WT isolates Pe3334, Pe3136, and Pe3175 had an $\mathrm{EC}_{50}$ of $0.04,0.04$, and $0.05 \mu \mathrm{g} / \mathrm{ml}$ for fludioxonil (FDL), respectively (data not shown). The $\mathrm{EC}_{50}$ values of the DIF-mutants for FDL were similar to those of the WT isolates and ranged from 0.04 to $0.06 \mu \mathrm{g} / \mathrm{ml}$. There was a moderate positive correlation $\left(R^{2}=0.4257\right)$ between $\mathrm{EC}_{50}$ values of FDL and DIF for DIFmutants adapted for 8 weeks on DIF at $2.5 \mu \mathrm{g} / \mathrm{ml}$ compared to the original UV mutants $\left(R^{2}=0.3567\right)$ (Figure 4A). DIF (Thesis) alone controlled the WT isolate Pe3175 but failed to control its two mutants M1 and M2, whereas FDL (pre-mixed with DIF) in Academy $^{\mathrm{TM}}$, applied preventively, fully controlled the WT isolate and its DIF-mutants after 6 months of storage at $1^{\circ} \mathrm{C}$ (Figure $4 \mathrm{~B}$ ).

\section{Sequence Analysis and Expression of the PeCYP51 Gene}

The sequencing of full PeCYP51 gene of $P$. expansum yielded a sequence with a length of 1751 bp with three introns of 68 , 69, and $63 \mathrm{bp}$, respectively, and coded for 516 amino acids (Figure 5A and Supplementary Figure S2). A blast of the amino acid sequence of the WT isolate Pe3175 revealed 100, 96, 92, and $67 \%$ identity with $P$. expansum, $P$. italicum, $P$. digitatum, and Aspergillus fumigatus accession numbers XP106598797, KGO74727, XP014532172, and ARS45267, respectively. The alignments of nucleotide and amino-acid sequences of the GenBank reference accession number XM016737741, the sensitive WT parental isolates, and the resulting DIF-mutants is shown in Figure 5B. A single polymorphism from A to $\mathrm{T}$ at nucleotide 445 resulted in an amino-acid substitution from tyrosine to phenylalanine at codon 126 (Y126F) of the PeCYP51 gene was detected in all mutants regardless of their $\mathrm{EC}_{50}$ value and was absent in all WT isolates (Figure 5B and Supplementary Figure S2). The CYP51 sequence from the Pe3175 WT-isolates and of its mutants (M1) were submitted to GenBank under the accession numbers MH507024 and MH507025, respectively.

We evaluated the CYP51 gene expression in 3 parental and 5 mutant isolates not challenged with DIF prior to RNA extraction. The relative expression (RE) of the CYP51 gene

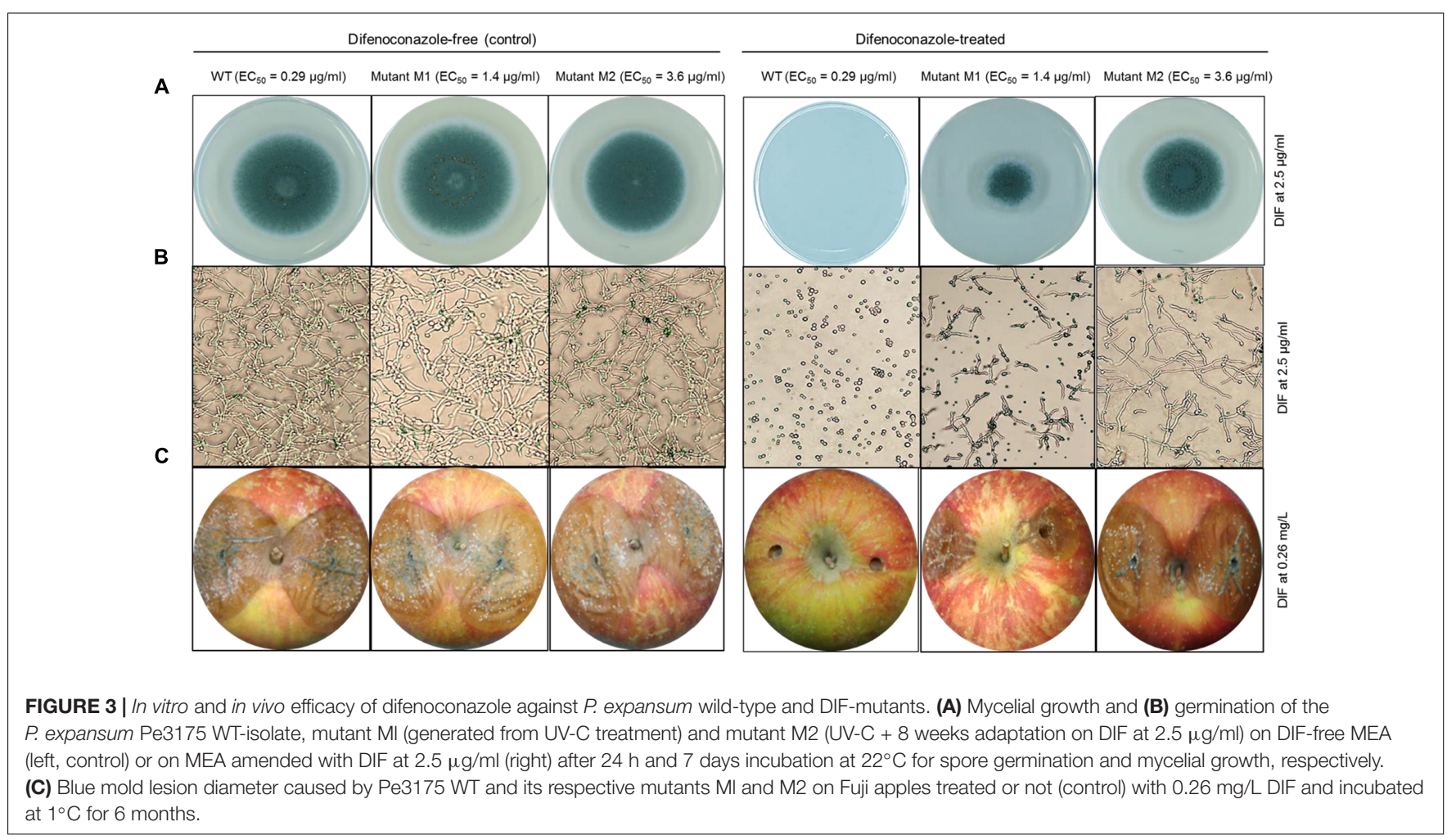


A

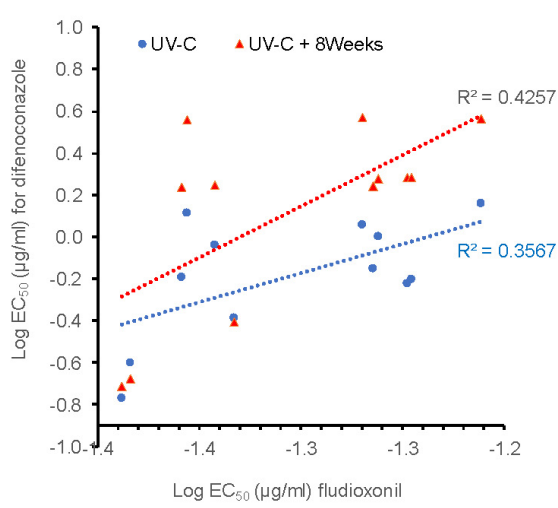

B

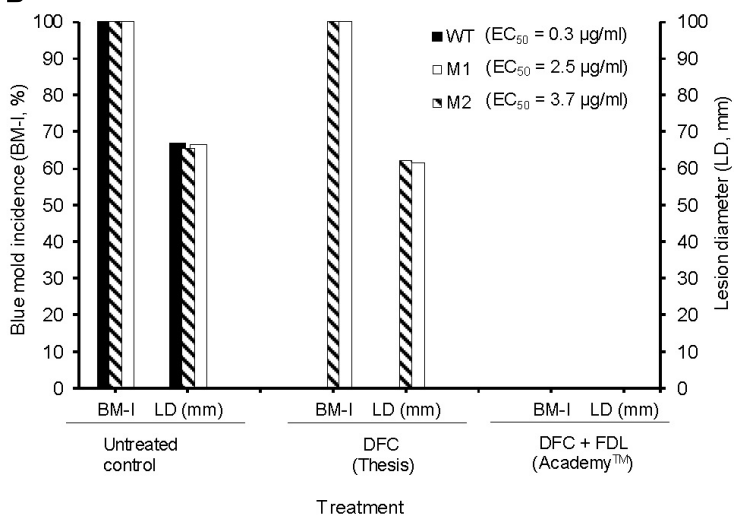

FIGURE 4 | In vitro and in vivo sensitivity of $P$. expansum DIF-mutants to fludioxonil. (A) Correlation between the LogEC 50 values of fludioxonil and difenoconazole for 12 isolates, i.e., the three WT-isolates and 9 resulting mutants immediately following UV-C excitation (blue) or UV-C followed by 8 weeks of selection pressure on MEA amended with DIF at $2.5 \mu \mathrm{g} / \mathrm{ml}$ (red). (B) Efficacy of DIF alone (Thesis) and DIF+FDL (Academy ${ }^{\mathrm{TM}}$ ) to control the WT-isolate Pe3175 and its mutants Ml and M2 after 6 months of storage at $1^{\circ} \mathrm{C}$. The efficacy was expressed as blue mold incidence (BM-I\%) and lesion diameter (LD, mm). Data are the mean of 16 values across 2 experimental runs for each isolate.

increased 2 to 3 folds in UV-mutants and 4 to 14 fold in mutants adapted for 8 weeks DIF at $2.5 \mu \mathrm{g} / \mathrm{ml}$ (Figure 6A). The CYP51RE was positively and significantly correlated $\left(R^{2}=0.8264\right)$ with the $\mathrm{EC}_{50}$ values of the isolates (Figure 6B). The mutants resulting from the Pe-3334 WT-isolate $\left(\mathrm{EC}_{50}=0.21 \mu \mathrm{g} / \mathrm{ml}\right)$ had a lower CYP51 RE compared to the mutants from the two other isolates after UV excitation or adaptation on DIF (Figure 6A).

\section{DISCUSSION}

Demethylation inhibitors have been used for years to control $P$. digitatum and P. italicum and other citrus pathogens. However, difenoconazole (DIF) is the first DMI registered for managing $P$. expansum and other postharvest diseases of pome fruit. The baseline $P$. expansum population was highly sensitive to DIF, as shown by the low $\mathrm{EC}_{50}$ values $(<0.5 \mu \mathrm{g} / \mathrm{ml})$ for all growth stages, i.e., germination, germ tube elongation, and mycelial growth, in vitro as well by the ability of DIF to fully control blue mold infections on apple fruits for at least 6 months in cold storage. High control efficacy of DIF has been reported in several ascomycetes such as Phacidiopycnis spp., Venturia inaequalis, Colletotrichum spp., Marssonina coronaria, Alternaria spp., and Fusarium spp. (Munkvold and O'Mara, 2002; Villani et al., 2015; Fonseka and Gudmestad, 2016; Cao et al., 2017; Dang et al., 2017; Ali et al., 2018) and the basidiomycete Rhizoctonia solani (Bartholomäus et al., 2017). Given the widespread occurrence of resistance to two of the three current postharvest fungicides and the stringent limitations to new postharvest fungicides registration, DIF could be a valuable additional tool to manage blue mold of pome fruit in the years to come if used appropriately and if its efficacy against other major postharvest diseases is proven.
Our data suggest a risk for P. expansum to develop resistance to DIF in packinghouses where it is expected to be part of regular management programs. This suggests it should be rotated with other fungicides, to extend its lifespan. The selection and characterization of $P$. expansum mutants in this study will be valuable to estimate the risk and the speed of DIF resistance development and will serve as a reference for future DIF resistance monitoring in exposed populations. Mutants with an $\mathrm{EC}_{50}$ value $>0.8 \mu \mathrm{g} / \mathrm{ml}$ were not controlled by the DIF label rate on detached fruit, and we, therefore, suggest a dose of $1.0 \mu \mathrm{g} / \mathrm{ml}$ and above as a potential discriminatory dose for future DIF resistance monitoring. Fitness penalties have been linked with resistance to other DMIs in multiple pathogens such as Monilinia fructicola, Aspergillus nidulans, and Colletotrichum truncatum (Van Tuyl, 1977; Chen et al., 2012; Zhang et al., 2017) but not in $P$. digitatum (Nakaune et al., 2002). We did not investigate the fitness of the DIF-P. expansum mutants, but the latter were as virulent at the parental wild-type isolates on apple fruit in the absence of a DIF selection pressure (Table 1). Moreover, although the level of resistance to DIF in the mutants slightly decreased over a 10-week period in the absence of a selection pressure in vitro, the $\mathrm{EC}_{50}$ values remained within the resistance range. Given that $P$. expansum is considered among the group of fungi with a "high risk" for fungicide resistance development, field resistance is likely to occur and persist in packinghouses if rational practices are not implemented immediately upon registration.

The mixture of DIF with fludioxonil as Academy ${ }^{\mathrm{TM}}$ should be effective in controlling DIF-resistant populations of P. expansum if/when they emerge in commercial packinghouses. Indeed, no cross-resistance was observed between FDL and DIF and the EC $_{50}$ values $(\leq 0.06 \mu \mathrm{g} / \mathrm{ml})$ of the DIF-mutants for FDL were not different from those of the parental isolates. There was a correlation with in vivo susceptibility as the label rate of Academy $^{\mathrm{TM}}$ fully controlled the DIF-resistant mutants on apple 


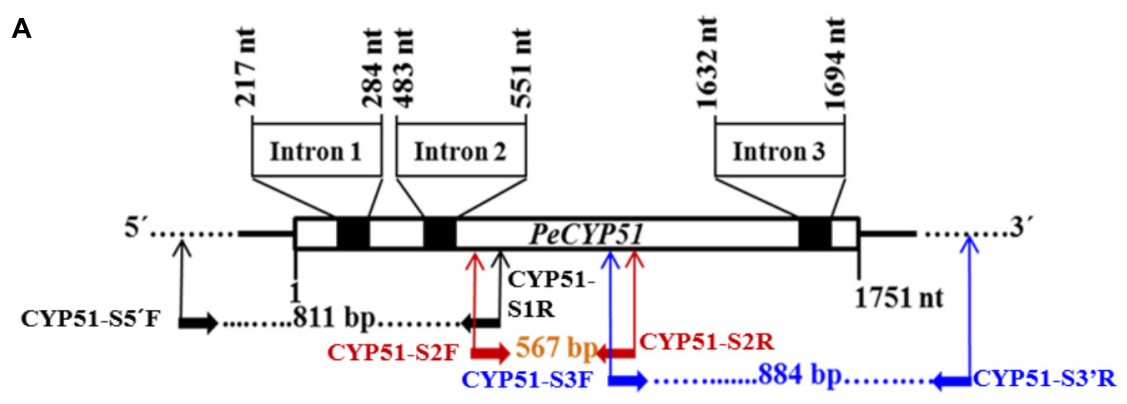

\begin{tabular}{|c|c|c|}
\hline Isolate & $\mathrm{EC}_{50}(\mu \mathrm{g} / \mathrm{ml})$ & サ̛ \\
\hline Pe-XM016737741 ${ }^{a}$ & $\ldots$ & 439- TAGT CTACGATT G \\
\hline Pe-3334-WT & 0.13 & 439- T A GT CTAC GATT G \\
\hline $\mathrm{Pe}-3136-\mathrm{WT}$ & 0.21 & 439- T A G T C T ACGAT T G \\
\hline $\mathrm{Pe}-3175-\mathrm{WT}$ & 0.29 & 439- T A GT C T AC GATT G \\
\hline Pe-3334-Mutant 1 & 1.3 & 439- T A G T C T T C GAT T G \\
\hline Pe-3334-Mutant 2 & 1.7 & 439- T A GT C T T C GAT T G \\
\hline Pe-3136-Mutant 1 & 1.3 & 439- T A G T C T T C GA T T G \\
\hline Pe-3136-Mutant 2 & 1.9 & 439- T A G T C T T C GAT T G \\
\hline Pe-3175-Mutant 1 & 2.5 & 439- T A G T C T T C GA T T G \\
\hline \multirow[t]{2}{*}{ Pe-3175-Mutant 2} & 3.7 & 439- TAGT C T T C GAT T G \\
\hline & & Nucleotide \\
\hline
\end{tabular}

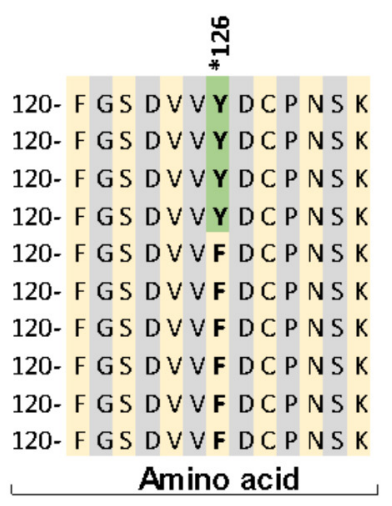

FIGURE 5 | Sequencing and nucleotide and amino acid sequence alignment of PeCYP51. (A) Schematic representation of the CYP51 gene of Penicillium expansum including the positions of the introns and primer binding sites used for CYP51 sequencing. (B) Nucleotide and amino acid sequences alignment of $P$. expansum isolates, with different $\mathrm{EC}_{50}$ values, i.e., 3 wild-type and 2 resulting mutants from each WT with the reference GenBank sequence accession \# XMO16737741. Asterisk indicates the nucleotide and codon (or equivalent) where a mutation has been seen and reported previously to confer resistance to DMl fungicides.
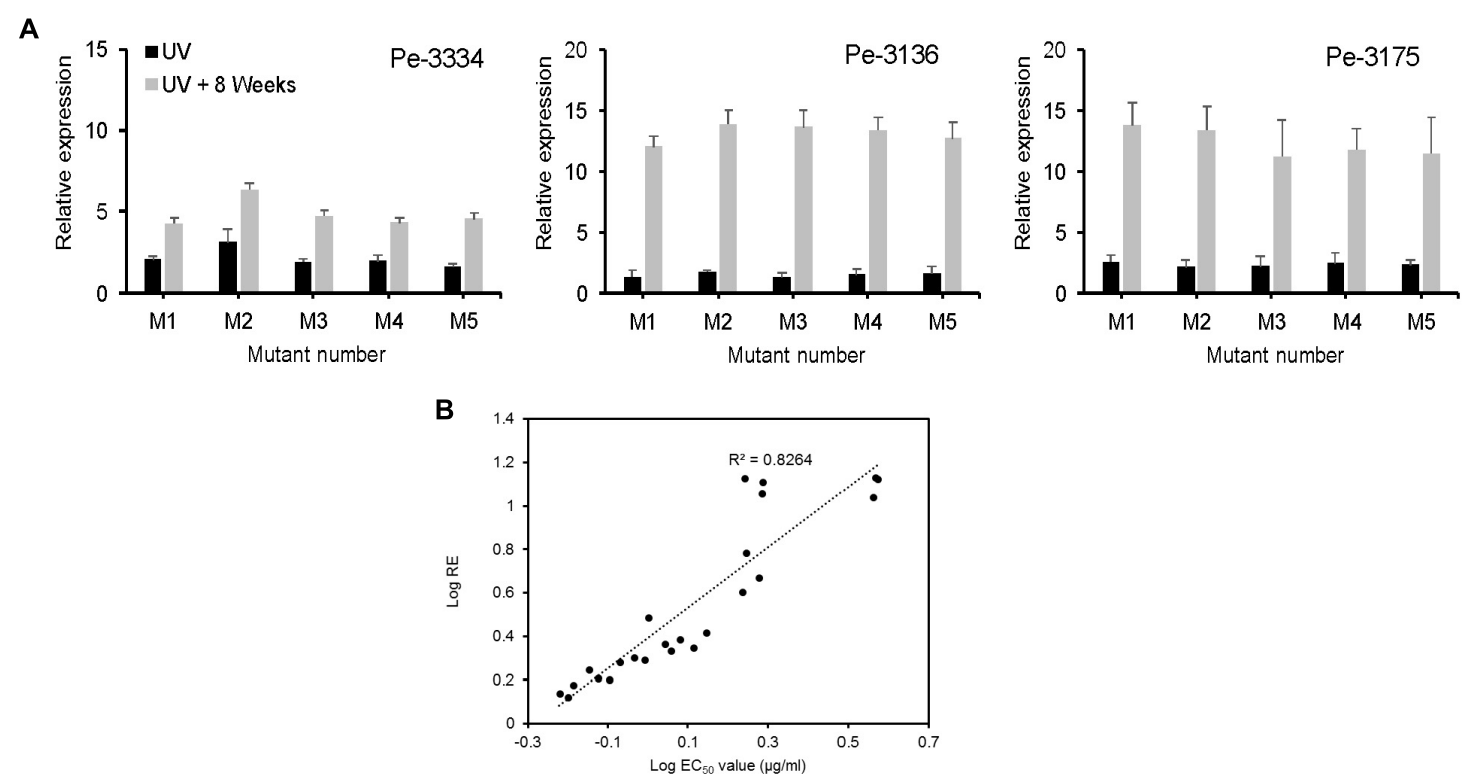

FIGURE 6 | Constitutive expression of PeCYP51 in Penicillium expansum and correlation with isolates sensitivity. (A) The relative expression was calculated with the reference $\beta$-actin gene using the $2^{-\Delta \Delta C t}$ method for 5 mutants from each of the three WT-isolates Pe3334, P3136, and Pe3175 after UV excitation (black columns) or after 8 weeks of selection pressure on MEA amended with $2.5 \mu \mathrm{g} / \mathrm{ml}$ (gray columns). The $\mathrm{EC}_{50}$ values of the mutants are shown in Table 1. The final relative expression (RE) was expressed as the RE in the mutant relative to the $\mathrm{RE}$ in the respective wild-type isolate. (B) Correlation between the LogEC $\mathrm{C}_{50}$ values of the $P$. expansum mutant isolates and their relative CYP51 expression. 
fruit after 6 months of storage (Figure 4B). However, because of a slightly stronger positive correlation (Figure 4A) observed between the $\mathrm{EC}_{50}$ values of FDL and DIF under a DIF-continuous selection pressure, further investigations are needed to ensure that mechanisms of resistance in P. expansum do not select for dual-resistant populations as it has been reported recently in the closely related species $P$. digitatum (Wang et al., 2014).

We present evidence that resistance to DMIs in $P$. expansum is likely caused by variation in the amino acid sequence and overexpression of the PeCYP51 gene, although other mechanisms cannot be completely excluded. The Tyr-Phe mutation found at codon 126 of $P$. expansum is well known for its role in resistance to DMIs as an equivalent mutation at codon 136 of Erysiphe necator (Délye et al., 1997, 1998; Frenkel et al., 2015), Blumeria graminis (Wyand and Brown, 2005), and Parastagonospora nodorum (Pereira et al., 2017) was reported to confer resistance to different DMIs. Other amino acid substitutions at different codons have also been reported to cause DMI resistance in several other plant pathogens (Leroux et al., 2007; Wang et al., 2015; Mair et al., 2016; Lichtemberg et al., 2017; Pereira et al., 2017). The Y126F substitution was present in all DIF mutants with an $\mathrm{EC}_{50}$ value $>1.0 \mu \mathrm{g} / \mathrm{ml}$ and no other mutation was detected in mutants with higher $\mathrm{EC}_{50}$ values $(>3 \mu \mathrm{g} / \mathrm{ml}$ ) after 8 weeks of selection pressure which suggest a major role of this alteration in conferring resistance to the DMI fungicides in P. expansum. If a single point mutation is proven to be the major driving factor of resistance to DIF and other DMIs in P. expansum, resistance can be expected to emerge and build-up quickly once DIF is used frequently in the packinghouses.

The Y126F alteration is located in the conserved substrate binding domain of the CYP51 gene (van Nestelrooy et al., 1996) and a mutation in this region could affect mRNA stability and heme structure of CYP51 which can decrease the affinity of DMIs as reported in Candida albicans (Kelly et al., 1999). The reduced affinity due to smaller amounts fungicide docking to the binding site prevents complete control. The significant 12 to 14-fold increase in the expression of the CYP51 gene without DIF induction prior to total RNA extraction in mutants of the second generation (selection pressure) suggests a role of CYP51 overexpression in DMI resistance in P. expansum. In the closely related species $P$. italicum and $P$. digitatum, several mechanisms of resistance to DMIs have been elucidated. Thus, the expression of the $P$. italicum-CYP51 gene by heterologous combination in Aspergillus niger was 2 to 5 -fold higher in a resistant transformant compared to a wild-type isolate, but whether a change in the amino-acid sequence has occurred was not investigated (van Nestelrooy et al., 1996). In the citrus green mold-causal species $P$. digitatum, resistance to DMIs has been linked to the $A B C$ and CYP51 genes. Penicillium multidrug resistance (PMR1 and PMR5) genes encoding an ATP-binding cassette were suggested to play a role in $P$. digitatum resistance to the DMIs (Nakaune et al., 1998, 2002; Sun et al., 2013) although the role of PMR1 was not clearly evidenced by Hamamoto et al. (2001b). Moreover, a 199 bp transposon insert in the promoter region of the CYP51 gene of $P$. digitatum DMI-resistant isolates increased its expression 7.5 to 13.6-fold (Ghosoph et al., 2007;
Sun et al., 2011), similar to the overexpression levels seen in $P$. expansum mutants in this study. Recently, a role of major facilitator superfamily transporters (MFS) has been hypothesized as potential mechanisms of DMI-resistance in P. digitatum (Wu et al., 2016). Worrisomely, some of the above mechanisms reported in $P$. digitatum were also found to confer multidrug (MDR) resistance (Nakaune et al., 2002; Sun et al., 2011). The $100 \mathrm{bp}$ sequenced upstream and downstream the CYP51 of $P$. expansum did not reveal any mutations in the DIF-mutants (data not shown). Research investigation is ongoing to explore additional potential mutations and study a potential role of the above or other mechanisms in DMI or MDR resistance of $P$. expansum populations in commercial packinghouses. This information will be critical to clearly assess the expected risk for resistance emergence in this pome fruit-Penicillium pathosystem and develop appropriate management strategies.

In summary, we conducted a risk assessment study to evaluate the efficacy and risk associated with the introduction of a new DMI in the pome fruit-postharvest system. We showed a high and lasting control efficacy of difenoconazole alone or in combination with fludioxonil. However, resistance to DIF seems likely to emerge in $P$. expansum packinghouse populations for which resistance levels and speed of selection will depend on the actual mechanism(s) of resistance and the selection pressure through usage frequency.

\section{AUTHOR CONTRIBUTIONS}

AA designed the project and supervised the work. EA performed the experiments and analyzed the data. All authors participated in writing and editing the manuscript.

\section{FUNDING}

This work was supported by a Washington Tree Fruit Research Commission (WTFRC) Grant no. AP-16105. PPNS \# 0766, Department of Plant Pathology, College of Agricultural, Human, and Natural Resource Sciences, Agricultural Research Center, Hatch Project No. WNP0555, Washington State University, Pullman, WA, United States.

\section{ACKNOWLEDGMENTS}

The authors thank Laxmi K. Pandit, WSU-TFREC for technical assistance and the WTFRC for funding.

\section{SUPPLEMENTARY MATERIAL}

The Supplementary Material for this article can be found online at: https://www.frontiersin.org/articles/10.3389/fmicb. 2018.02472/full\#supplementary-material 


\section{REFERENCES}

Ali, E. M., Pandit, L. K., Mulvaney, K. A., and Amiri, A. (2018). Sensitivity of Phacidiopycnis spp. isolates from pome fruit to six pre- and postharvest fungicides. Plant Dis. 102, 533-539.

Amiri, A., and Ali, E. M. (2016). Prevalence of Storage Decays of Apple: Lessons from the 2016 Statewide Survey. Available at: http://treefruit.wsu.edu/news/ prevalence-of-storage-decays-of-apple-lessons-from-the-2016-statewidesurvey/

Amiri, A., Ali, E. M., De Angelis, D. R., Mulvaney, K. A., and Pandit, L. K. (2018). "Prevalence and distribution of Penicillium expansum and Botrytis cinerea in apple packinghouses across Washington State and their sensitivity to the postharvest fungicide-pyrimethanil," in Proceedings of IV International Symposium on Postharvest Pathology, Skukuza.

Amiri, A., Mulvaney, K. A., and Pandit, L. K. (2017). First report of Penicillium expansum isolates with low levels of resistance to fludioxonil from commercial apple packinghouses in Washington State. Plant Dis. 101, 835-835. doi: 10. 1094/PDIS-09-16-1353-PDN

Amiri, A., and Bompeix, G. (2005a). Diversity and population dynamics of Penicillium spp. on apples in pre-and postharvest environments: consequences for decay development. Plant Pathol. 54, 74-81. doi: 10.1111/j.1365-3059.2005. 01112.x

Amiri, A., and Bompeix, G. (2005b). Micro-wound detection on apple and pear fruit surfaces using sulfur dioxide. Postharvest Biol. Technol. 36, 51-59. doi: 10.1016 /j.postharvbio.2004.10.010

Bartholomäus, A., Mittler, S., Märländer, B., and Varrelmann, M. (2017). Control of Rhizoctonia solani in sugar beet and effect of fungicide application and plant cultivar on inoculum potential in the soil. Plant Dis. 101, 941-947. doi: 10.1094/PDIS-09-16-1221-RE

Bus, V., Bongers, A., and Risse, L. (1991). Occurrence of Penicillium digitatum and $P$. italicum resistant to benomyl, thiabendazole and imazalil on citrus fruit from different geographic origins. Plant Dis. 75, 1098-1100. doi: 10.1094/PD75- 1098

Caiazzo, R., Kim, Y., and Xiao, C. (2014). Occurrence and phenotypes of pyrimethanil resistance in Penicillium expansum from apple in Washington state. Plant Dis. 98, 924-928. doi: 10.1094/PDIS-07-13-0 721-RE

Cao, X., Xu, X., Che, H., West, H. S., and Luo, D. (2017). Distribution and fungicide sensitivity of Colletotrichum species complexes from rubber tree in Hainan. China Plant Dis. 101, 1774-1780. doi: 10.1094/ PDIS-03-17-0352-RE

Chen, F. P., Fan, J. R., Zhou, T., Liu, X. L., Liu, J. L., and Schnabel, G. (2012). Baseline sensitivity of Monilinia fructicola from China to the DMI fungicide SYP-Z048 and analysis of DMI-resistant mutants. Plant Dis. 96, 416-422. doi: 10.1094/PDIS-06-11-0495

Dang, J., Gleason, M., Niu, C., Liu, X., Guo, Y., Zhang, R., et al. (2017). Effects of fungicides and spray application interval on controlling Marssonina blotch of apple in the Loess Plateau Region of China. Plant Dis. 101, 568-575. doi: 10.1094/PDIS-04-16-0464-RE

Délye, C., Bousset, L., and Corio-Costet, M. F. (1998). PCR cloning and detection of point mutations in the eburicol 14 alpha-demethylase (CYP51) gene from Erysiphe graminisf. sp. hordei, a "recalcitrant" fungus. Curr. Genet. 34, 399-403. doi: $10.1007 / \mathrm{s} 002940050413$

Délye, C., Laigret, F., and Corio-Costet, M.-F. (1997). A mutation in the 14 alpha-demethylase gene of Uncinula necator that correlates with resistance to a sterol biosynthesis inhibitor. Appl. Environ. Microbiol. 63, 2966-2970.

Diaz-Guerra, T., Mellado, E., Cuenca-Estrella, M., and Rodriguez-Tudela, J. (2003). A point mutation in the $14 \alpha$-sterol demethylase gene cyp51A contributes to itraconazole resistance in Aspergillus fumigatus. Antimicrob. Agents Chemother. 47, 1120-1124. doi: 10.1128/AAC.47.3.1120-1124. 2003

Eckert, J. W., and Ogawa, J. M. (1988). The chemical control of postharvest diseases: deciduous fruits, berries, vegetables and root/tuber crops. Ann. Rev. Phytopathol. 26, 433-469. doi: 10.1146/annurev.py.26.090188. 002245

Erickson, E. O., and Wilcox, W. F. (1997). Distributions of sensitivities to three sterol demethylation inhibitor fungicides among populations of Uncinula necator sensitive and resistant to triadimefon. Phytopathology 87, 784-791. doi: 10.1094/PHYTO.1997.87. 8.784

Errampalli, D., Brubacher, N. R., and DeEll, J. R. (2006). Sensitivity of Penicillium expansum to diphenylamine and thiabendazole and postharvest control of blue mold with fludioxonil in 'McIntosh'apples. Postharvest Biol. Technol. 39, 101-107. doi: 10.1016/j.postharvbio.2005. 09.008

Favre, B., Didmon, M., and Ryder, N. S. (1999). Multiple amino acid substitutions in lanosterol $14 \alpha$-demethylase contribute to azole resistance in Candida albicans. Microbiology 145, 2715-2725. doi: 10.1099/00221287 $-145-10-2715$

Fonseka, D., and Gudmestad, N. (2016). Spatial and temporal sensitivity of Alternaria species associated with potato foliar diseases to demethylation inhibiting and anilino-pyrimidine fungicides. Plant Dis. 100, 1848-1857. doi: 10.1094/PDIS-01-16-0116-RE

Fraaije, B., Cools, H., Kim, S. H., Motteram, J., Clark, W., and Lucas, J. (2007). A novel substitution I381V in the sterol $14 \alpha$-demethylase (CYP51) of Mycosphaerella graminicola is differentially selected by azole fungicides. Mol. Plant Pathol. 8, 245-254. doi: 10.1111/j.1364-3703.2007. 00388.x

Frenkel, O., Cadle-Davidson, L., Wilcox, W. F., and Milgroom, M. G. (2015). Mechanisms of resistance to an azole fungicide in the grapevine powdery mildew fungus Erysiphe necator. Phytopathology 105, 370-377. doi: 10.1094/ PHYTO-07-14-0202-R

Gaskins, V. L., Vico, I., Yu, J., and Yurick, W. M. (2015). First report of Penicillium expansum isolates with reduced sensitivity to fludioxonil from a commercial packinghouse in Pennsylvania. Plant Dis. 99:1182. doi: 10.1094/PDIS-11-141161-PDN

Ghosoph, J. M., Schmidt, L. S., Margosan, D. A., and Smilanick, J. L. (2007). Imazalil resistance linked to a unique insertion sequence in the PdCYP51 promoter region of Penicillium digitatum. Postharvest Biol. Technol. 44, 9-18. doi: $10.1016 /$ j.postharvbio.2006.11.008

Golembiewski, R., Vargas, J., Jones, A., and Detweiler, A. (1995). Detection of demethylation inhibitor (DMI) resistance in Sclerotinia homoeocarpa populations. Plant Dis. 79, 491-493. doi: 10.1094/PD-790491

Hall, T. A. (1999). BioEdit. A user-friendly biological sequence alignment editor and analysis program for windows 95/98/NT. Nucleic Acids Symp. Ser. 41, 95-98.

Hamamoto, H., Hasegawa, K., Nakaune, R., Lee, Y. J., Makizumi, Y., Akutsu, K., et al. (2001a). Tandem repeat of a transcriptional enhancer upstream of the sterol $14 \alpha$-demethylase gene (CYP51) in Penicillium digitatum. Appl. Environ. Microbiol. 66, 3421-3426. doi: 10.1128/AEM. 66.8.3421-3426.2000

Hamamoto, H., Nawata, O., Hasegawa, K., Nakaune, R., Lee, Y. J., Makizumi, Y., et al. (2001b). The role of the ABC transporter gene PMR1 in demethylation inhibitor resistance in Penicillium digitatum. Pest Biochem. Physiol. 70, 19-26. doi: $10.1006 /$ pest.2000.2530

Hellemans, J., Mortier, G., De Paepe, A., Speleman, F., and Vandesompele, J. (2007). qBase relative quantification framework and software for management and automated analysis of real-time quantitative PCR data. Genome Biol. 8:R19. doi: $10.1186 / \mathrm{gb}-2007-8-2-r 19$

Hof, H. (2001). Critical annotations to the use of azole antifungals for plant protection. Antimicrob. Agents Chemother. 45, 2987-2990. doi: 10.1128/AAC. 45.11.2987-2990.2001

Joseph-Horne, T., and Hollomon, D. W. (1997). Molecular mechanisms of azole resistance in fungi. FEMS Microbiol. Lett. 149, 141-149. doi: 10.1111/j.15746968.1997.tb10321.x

Jurick, W. M., Janisiewicz, W. J., Saftner, R. A., Vico, I., Gaskins, V. L., Park, E. et al. (2011). Identification of wild apple germplasm (Malus spp.) accessions with resistance to the postharvest decay pathogens Penicillium expansum and Colletotrichum acutatum. Plant Breed. 130, 481-486. doi: 10.1111/j.1439-0523. 2011.01849.x

Jurick, W. M., Macarisin, O., Gaskins, V. L., Park, E., Yu, J., Janisiewicz, W. et al. (2017). Characterization of postharvest fungicide-resistant Botrytis cinerea isolates from commercially stored apple fruit. Phytopathology 107, 362-368. doi: 10.1094/PHYTO-07-16-0250-R 
Kelly, S. L., Lamb, D. C., Loeffler, J., Einsele, H., and Kelly, D. E. (1999). The G464S amino acid substitution in Candida albicans sterol 14 alphademethylase causes fluconazole resistance in the clinic through reduced affinity. Biochem. Biophys. Res. Commun. 262, 174-179. doi: 10.1006/bbrc.1999. 1136

Koehler, A., and Shew, H. (2018). Field efficacy and baseline sensitivity of Septoria steviae to fungicides used for managing Septoria leaf spot of stevia. Crop Prot. 109, 95-101. doi: 10.1016/j.cropro.2018.03.006

Leroux, P., Albertini, C., Gautier, A., Gredt, M., and Walker, A.-S. (2007). Mutations in the CYP51 gene correlated with changes in sensitivity to sterol $14 \alpha$-demethylation inhibitors in field isolates of Mycosphaerella graminicola. Pest Manag. Sci. 63, 688-698. doi: 10.1002/ps. 1390

Li, H. X., and Xiao, C. L. (2008). Resistance to fludioxonilresistant and pyrimethanil-resistant phenotypes of Penicillium expansum from apple. Phytopathology 98, 427-435. doi: 10.1094/ PHYTO-98-4-0427

Lichtemberg, P. S. F., Luo, Y., Morales, R. G., Muehlmann-Fischer, J. M., Michailides, T. J., and May De Mio, L. L. (2017). The point mutation g461s in the mfcyp51 gene is associated with tebuconazole resistance in Monilinia fructicola populations in Brazil. Phytopathology 107, 1507-1514. doi: 10.1094/ PHYTO-02-17-0050-R

Livak, K. J., and Schmittgen, T. D. (2001). Analysis of relative gene expression data using real-time quantitative PCR and the 2(T)(-Delta Delta C) method. Methods 25, 402-408. doi: 10.1006/meth.2001.1262

Mair, W. J., Deng, W., Mullins, J. G. L., West, S., Wang, P., Besharat, N., et al. (2016). demethylase inhibitor fungicide resistance in Pyrenophora teres f. sp. teres associated with target site modification and inducible overexpression of Cyp51. Front. Microbiol. 7:1279. doi: 10.3389/fmicb.2016.01279

Malandrakis, A. A., Markoglou, A. N., Konstantinou, S., Doukas, E. G., Kalampokis, J. F., and Karaoglanidis, G. S. (2013). Molecular characterization, fitness and mycotoxin production of benzimidazole-resistant isolates of Penicillium expansum. Int. J. Food Microbiol. 162, 237-244. doi: 10.1016/j. ijfoodmicro.2013.01.014

Mellado, E., Garcia-Effron, G., Alcazar-Fuoli, L., Melchers, W., Verweij, P., Cuenca-Estrella, M., et al. (2007). A new Aspergillus fumigatus resistance mechanism conferring in vitro cross-resistance to azole antifungals involves a combination of CYP51A alterations. Antimicrob. Agents Chemother. 51, 1897-1904. doi: 10.1128/AAC.01092-06

Morales, H., Marín, S., Rovira, A., Ramos, A. J., and Sanchis, V. (2007). Patulin accumulation in apples by Penicillium expansum during postharvest stages. Lett. Appl. Microbiol. 44, 30-35. doi: 10.1111/j.1472-765X.2006.02035.x

Munkvold, G. P., and O'Mara, J. K. (2002). Laboratory and growth chamber evaluation of fungicidal seed treatments for maize seedling blight caused by Fusarium species. Plant Dis. 86, 143-150. doi: 10.1094/PDIS.2002.86.2.143

Nakaune, R., Adachi, K., Nawata, O., Tomiyama, M., Akutsu, K., and Hibi, T. (1998). A novel ATP-binding cassette transporter involved in multidrug resistance in the phytopathogenic fungus Penicillium digitatum. Appl. Environ. Microbiol. 64, 3983-3988.

Nakaune, R., Hamamoto, H., Imada, J., Akutsu, K., and Hibi, T. (2002). A novel ABC transporter gene. Mol. Genet. Genomics 267, 179-185. doi: 10.1007/ s00438-002-0649-6

Omrane, S., Sghyer, H., Audéon, C., Lanen, C., Duplaix, C., Walker, A. S., et al. (2015). Fungicide efflux and the MgMFS1 transporter contribute to the multidrug resistance phenotype in Zymoseptoria tritici field isolates. Environ. Microbiol. 17, 2805-2823. doi: 10.1111/1462-2920.12781

Pereira, D. A. S., McDonald, B. A., and Brunner, P. C. (2017). Mutations in the CYP51 gene reduce DMI sensitivity in Parastagonospora nodorum populations in Europe and China. Pest Manag. Sci. 73, 1503-1510. doi: 10.1002/ ps.4486

Reimann, S., and Deising, H. B. (2005). Inhibition of efflux transportermediated fungicide resistance in Pyrenophora tritici-repentis by a derivative of 4'-hydroxyflavone and enhancement of fungicide activity. Appl. Environ. Microbiol. 71, 3269-3275. doi: 10.1128/AEM.71.6.3269-3275.2005

Rodriguez, R. J., Low, C., Bottema, C. D. K., and Parks, L. W. (1985). Multiple functions for sterols in Saccharomyces cerevisiae. Biochim. Biophys. Acta 837, 336-343. doi: 10.1016/0005-2760(85)90057-8
Rosenberger, D., Wicklow, D., Korjagin, V., and Rondinaro, S. (1991). Pathogenicity and benzimidazole resistance in Penicillium species recovered from flotation tanks in apple packinghouses. Plant Dis. 75, 712-715. doi: 10. 1094/PD-75-0712

Sanderson, P., and Spotts, R. (1995). Postharvest decay of winter pear and apple fruit caused by species of Penicillium. Phytopathology 85, 103-110. doi: 10.1094/ Phyto-85-103

Schnabel, G., and Jones, A. L. (2001). The 14 $\alpha$-Demethylasse (CYP51A1) gene is overexpressed in Venturia inaequalis strains resistant to myclobutanil. Phytopathology 91, 102-110. doi: 10.1094/PHYTO.2001. 91.1.102

Sholberg, P. L., Harlton, C., Haag, P., Levesque, C. A., O'Gorman, D., and Seifert, K. (2005). Benzimidazole and diphenylamine sensitivity and identity of Penicillium spp. that cause postharvest blue mold of apples using betatubulin gene sequences. Postharvest Biol. Technol. 36, 41-49. doi: 10.1094/ PD-89-1143

Snelders, E., van der Lee, H. A. L., Kuijpers, J., Rijs, A. J. M. M., Varga, J., Samson, R. A., et al. (2008). Emergence of azole resistance in Aspergillus fumigatus and spread of a single resistance mechanism. PLoS Med. 5:e219. doi: 10.1371/ journal.pmed.0050219

Spotts, R., and Cervantes, L. (1993). Filtration to remove spores of Penicillium expansum from water in pome fruit packinghouses. Tree Fruit Postharvest $J$. $4,16-18$.

Sun, X., Ruan, R., Lin, L., Zhu, C., Zhang, T., Wang, M., et al. (2013). Genome wide investigation into DNA elements and $\mathrm{ABC}$ transporters involved in imazalil resistance in Penicillium digitatum. FEMS Microbiol. Lett. 348, 11-18. doi: 10. $1111 / 1574-6968.12235$

Sun, X., Wang, J., Feng, D., Ma, Z., and Li, H. (2011). PdCYP51B, a new putative sterol $14 \alpha$-demethylase gene of Penicillium digitatum involved in resistance to imazalil and other fungicides inhibiting ergosterol synthesis. Appl. Microbiol. Biotechnol. 91:1107. doi: 10.1007/s00253-0113355-7

Van Den Brink, H. J. M., Van Nistelrooy, H. J. G. M., De Waard, M. A., Van Den Honde, C. A. M. J. J., and Van Gorcom, R. F. M. (1996). Increased resistance to $14 \alpha$-demethylase inhibitors (DMIs) in Aspergillus niger by coexpression of the Penicillium italicum eburicol $14 \alpha$-demethylase (cyp51) and the A. niger cytochrome P450 reductase (cprA) genes. J. Biotechnol. 49, 13-18. doi: 10.1016/ 0168-1656(96)01403-4

van Nestelrooy, J. G. M., van den Brink, J. M., van Kan, J. A. L., van Gorcom, R. F. M., and de Waard, M. A. (1996). Isolation and molecular characterization of the gene encoding eburicol $14 \alpha$-demethylase (CYP51) from Penicillium italicum. Mol. Gen. Genet. 250, 725-733.

Van Tuyl, J. M. (1977). Genetics of fungal resistance to systemic fungicides. Mededelingen Landbouwhogeschool Wageningen 77, 1-136.

Villani, S. M., Biggs, A. R., Cooley, D. R., Raes, J. J., and Cox, K. D. (2015). Prevalence of myclobutanil resistance and difenoconazole insensitivity in populations of Venturia inaequalis. Plant Dis. 99, 1526-1536. doi: 10.1094/ PDIS-01-15-0002-RE

Wang, F., Lin, Y., Yin, W.-X., Peng, Y.-L., Schnabel, G., Huang, J.-B., et al. (2015). The Y137H mutation of VvCYP51 gene confers the reduced sensitivity to tebuconazole in Villosiclava virens. Sci. Rep. 5:17575. doi: 10.1038/ srep17575

Wang, M., Chen, C., Zhu, C., Sun, X., Ruan, R., and Li, H. (2014). Os2 MAP kinase-mediated osmostress tolerance in Penicillium digitatum is associated with its positive regulation on glycerol synthesis and negative regulation on ergosterol synthesis. Microbiol. Res. 169, 511-521. doi: 10.1016/j.micres.2013. 12.004

Wu, Z., Wang, S., Yuan, Y., Zhang, T., Liu, J., and Liu, D. (2016). A novel major facilitator superfamily transporter in Penicillium digitatum (PdMFS2) is required for prochloraz resistance, conidiation and full virulence. Biotechnol. Lett. 38, 1349-1357. doi: 10.1007/s10529-016-2113-4

Wyand, R. A., and Brown, J. K. M. (2005). Sequence variation in the CYP51 gene of Blumeria graminis associated with resistance to sterol demethylase inhibiting fungicides. Fungal Genet. Biol. 42, 726-735. doi: 10.1016/j.fgb.2005. 04.007

Yan, H. J., Gaskins, V. L., Vico, I., Luo, Y. G., and Jurick, W. M. (2014). First report of Penicillium expansum isolates resistant to pyrimethanil 
from stored apple fruit in Pennsylvania. Plant Dis. 98, 1004-1004. doi: 10.1094/PDIS-12-13-1214-PDN

Yin, Y. N., and Xiao, C. L. (2013). Molecular characterization and a multiplex allelespecific PCR method for detection of thiabendazole resistance in Penicillium expansum from apple. Eur. J. Plant Pathol. 136, 703-713. doi: 10.1007/s10658013-0199-2

Zhang, C., Diao, Y., Wang, W., Hao, J., Imran, M., Duan, H. X., et al. (2017). Assessing the risk for resistance and elucidating the genetics of Colletotrichum truncatum that is only sensitive to some DMI fungicides. Front. Microbiol. 8:1779. doi: 10.3389/fmicb.2017.01779
Conflict of Interest Statement: The authors declare that the research was conducted in the absence of any commercial or financial relationships that could be construed as a potential conflict of interest.

Copyright (c) 2018 Ali and Amiri. This is an open-access article distributed under the terms of the Creative Commons Attribution License (CC BY). The use, distribution or reproduction in other forums is permitted, provided the original author(s) and the copyright owner(s) are credited and that the original publication in this journal is cited, in accordance with accepted academic practice. No use, distribution or reproduction is permitted which does not comply with these terms. 